DOI: https://doi.org/10.3126/njdrs.v15i0.31591

\title{
Local Governance Practices in Federal Context: The Case of Gorkha Municipality
}

\author{
Bipin Dhital \\ Program Coordinator, Poverty Alleviation Fund (PAF) \\ Tahachal, Kathmandu, Nepal \\ Email for correspondence: bipindhita12003@gmail.com
}

\begin{abstract}
This study highlighted on examining/appraising local governence practices of Nepal in federal context. The study was conducted in Gorkha Municipality located in Gorkha district. The respondents/ participants were elected representatives and administrative staffs selected purposively. Necessary data/information were collected through institutional survey, KII, FGD and participant observation techniques. The study found poor physical infrastructure facilities of municipal office for offering efficient administrative services. Eventhough, the administrative staffs are newly appointed young generation found active and interactive. They are accountable and accessible to the service receivers and offering effective and quality service delivery. Elected representatives are also found educated having managerial and leadership skills since they were came from the background of social work. In this federal context, devolved power/jurisdictions of local government in general and Gorkha Municipality in particular have so many opportunities for implementing rural development related programs/projects. However, local government still has been facing challenges of physical infrastructure, economic resources and sufficient human resources.
\end{abstract}

Key words: Federal governance, local governance, institutional capacity, service delivery

\section{Background}

The People Movement 1990 demolished 30 year's partyless Panchayat polity and restored democracy with constitutional monarchy system. With the promulgation of Constitution of Kingdom Nepal (1990), there was much dissatisfaction which resulted into Maoist's armed conflict (1996-2006). The People's Movement 2006 and the subsequent Comprehensive Peace Accord (CPA) provided a comprehensive discourse of socio-political issues, including state-restructuring and constitution writing. Historically, election for Constituent Assembly (CA) happened in 2008 but it couldn't give new constitution due to issue of federalism and restructuring state. Second election of the CA held in 2013 and it has provided new constitution in 20th September 2015.

The paradigm of political transition has been rapidly changing in Nepal with the promulgation of a new Constitution in 2015 September. The constitution has ensured sovereignty of people in the federal context. It has defined Nepal nation-state as an independent, invisible, sovereign, secular, inclusive, democratic, socialism-oriented, federal democratic republican state (LBMB, 2015). With the devolution of power and rights to local levels in federal system, there a number of opportunities as well as several challenges in terms of service delivery mechanism. Nepal has adopted a federal governing 
system as its purpose by holding together for a diverse social structure including caste/ethnic groups (e.g. Khas-Arya, Indigenous ethnic groups, and Madhesi), different regions and minority sections of the society. Constitutionally, there are three-levels of governments (i.e. federation at centeral level, provincial government at regional level and local government at local levels) in Nepal. The local government includes District Coordination Committee, Municipality and Rural Municipality (LBMB, 2017).

Although the Interim Constitution 2007 guarantees federalism through its first amendment, as far back as the 1950s a regional party called the Tarai Congress demanded a Tarai Autonomous Region in a federal set up. However, federalism did not gain wide public support, even in the Tarai, and the idea faded from public consciousness soon after. Since the restoration of democracy in 1990, Nepal saw the rise of ethnicity as a socio-political identity among Nepal's various groups and the demand for inclusive democracy, including federalism, by ethnic groups slowly gained ground. Federalism became a subject of scholarly debate in conferences and a few articles and books were also written on the subject (e.g., Baral, 2004; Tamang, 2005; Lawoti, 2005; Mulyankan Monthly) before it formally received its place in the Interim Constitution. However, federalism was not a system that appealed to most major political forces and, until recently, was considered a radical and unchartered course (Sharma, 2006). When the then CPN (Maoist) entered into negotiations with the government for the second time in April 2003, it proposed that the essence of the new constitution should be to guarantee ethnic and regional autonomy for suppressed caste/ethnic groups, Madhesis and ignored regions, with the right to self-determination (Sharma \& Pokhrel, 2004). The Madhes uprising, which took place immediately after the Interim Constitution was promulgated in 2007, led to the first amendment in April 2007, which guaranteed a federal structure for Nepal.

The Constitution of Nepal (2015) has formally declared Nepali nation-state as a 'Federal Republic Nepal'. Typology of Federal system in Nepal is cooperative Federalism in where all provinces are assumed to be co-existed, interdependent and interconnected to each other. The federal operation system is hierarchical i.e. constitution is powerful, a federal government is in national level, seven state governments are in seven province level and local governments are at each local levels including DCC in each district level (LMBM, 2015). The Constitution of Nepal (2015) has provisioned powers to the local levels. Under the provisioned powers to the local levels, the local government perform and provide administrative services to the public.

\section{Objectives}

- To analyze institutional capacity of Gorkha municipality.

- To assess the effectiveness of administrative service delivery of the municipality.

- To analyze the existing opportunities and challenges of local government regarding to administrative service delivery.

\section{Materials and Methods}

This study applied mixed method approach as the research issues are explainatory (quantitative) and exploratory (qualitative) in nature (Flick, 2014). More specifically, the quantitative data are collected through institutial survey wheras qualitative information or narrations are generated by applying KII, FGD and Observation Techniques (Table 1). 
Table 1. Selection of the Respondents/participants and Techniques of Data Collection

\begin{tabular}{|c|c|c|}
\hline Approach & Tool & Description \\
\hline Quantitative & - Institutional Survey & $\begin{array}{l}\text { Institutional survey (in each wards and the } \\
\text { municipal office) }\end{array}$ \\
\hline \multirow[t]{3}{*}{ Qualitative } & - $\quad$ KIIs & $\begin{array}{l}8 \text { in total KIIs (with major political leaders, } \\
\text { chairpersons of each ward, Mayor and Ex- } \\
\text { ecutive Officer) }\end{array}$ \\
\hline & - $\quad$ FGDs & $\begin{array}{l}\text { Five FGDs in total (one in each ward; and } \\
\text { one in the municipality office) }\end{array}$ \\
\hline & - Observation methods & o Ward offices and municipality offices \\
\hline
\end{tabular}

(Field Study, 2018)

Similarly, during data analysis more cocus were given to devolved power/jurisdictions of constitutional provision, status of governence system of local government, reflections of servicer providers regarding to administrative services and reflections of elected representatives regarding administrative services. This study analyzed effectiveness of service delivery functions based on constitutional and legal framework, institutional capacity, and service delivery mechanism.

\section{Results: Profile of the Ward Chairs}

The elected representatives were found to be of different socio-economic and professional backgrounds. There are 5 chairpersons in five wards or having one chair in the each (Table 2 [Ward chairperson only] $)^{1}$ Out of them, four are males and one female. Male-dominance is thus seen in the leadership. Regarding the caste/ethnic orientation, upper caste are dominant along with 3 chairpersons. This was followed by three indigenous chairpersons, but not one Dalit were there in such leadership position of the ward. In terms of education, most of them had a qualification of secondary level, whereas only one chairperson completed intermediate level. Their occupations seemed mixed; two chairpersons being entrepreneur, two social workers and only one a politician, but no one having farming or agricultural status.

Table 2. Profiles of Ward Chairs

\begin{tabular}{lllll}
\hline Wards & Sex & $\begin{array}{l}\text { Ethnicity/ } \\
\text { Caste }\end{array}$ & Education & $\begin{array}{l}\text { Occupational } \\
\text { background }\end{array}$ \\
5 & & Ind & Sec & Politician \\
6 & $\mathrm{M}$ & $\mathrm{BC}$ & $\mathrm{Sec}$ & Social worker \\
8 & $\mathrm{M}$ & $\mathrm{Ind}$ & $\mathrm{Int}$ & Entrepreneur \\
9 & $\mathrm{~F}$ & $\mathrm{BC}$ & $\mathrm{Sec}$ & Entrepreneur \\
10 & $\mathrm{M}$ & $\mathrm{BC}$ & $\mathrm{Sec}$ & Social worker \\
Total (5) & M & & & \\
\hline
\end{tabular}

(Institutional Survey, 2018)

1 Indications: M (male), F (female), Sec (secondary), Int (Intermediate), BC (Brahman-Chhetri), Ind (indigenous nationalities), etc.

Nepalese Journal of Development and Rural Studies, Volume 15, 2018 


\section{Profile of the Members of the Wards}

As according to constitutional provision, there are 5 elected representatives at the ward level. The ward committee is ensured with the representation of diverse cultural setting, not excluding dalit, janajati and backward/ minority class people (Table 3). There are 20 members of the ward in total under the sample of this study; five wards having one chair and 4 members in the each. Out of them, genderbalance is thus seen in the selected ward committees. The Constitution of Nepal has already provision of female participation in each ward committee. The researcher tried to assess the participation in ward committee from the perspective of gender, is there more female or low in terms of regarding percent or legal provision. The table 3 shows that the participation of female in governance is more than national standard of Nepal i.e. 33 percent of female participation in governing mechanism.

Regarding the caste/ethnic orientation, indigenous ethnic groups are dominant along with 12 members. This was followed by three dalit members, but only two members from upper-caste groups was evident in the survey wards. The education is enlightenment for development. It is essential from formulating plan of development to establish a mechanism for making service delivery effective. Hence, the researcher interested to assess academic background of the elected representatives. Constitutionally, there is not any provision to be passed academic level to be elected representatives of local levels. In terms of educational attainment, most of them had a qualification of lower secondary level (9 members), whereas only few members completed higher level of the education, including four members secondary level, four intermediate level and one member having bachelor level. Knowledge of previous occupational background is one of the major inputs for making the changes in anything either it is administrative service delivery or other development activities. Hence, the researcher also assessed to the occupational background of the representatives of the municipality. In the same way, their occupations of the elected members of the sampled wards seemed mixed; eight members being entrepreneur, five social workers, and seven farmers but no one as a politician. The findings reflected that the majority of the representatives are entrepreneurs and social workers. Hence, they are capable for making any decision for efficient and effective public service delivery whether it is related administrative section or development. It is so because they are very familiar with innovative ideas for accelerating efficient working modality.

Table 3. Profile of Elected Representatives (Ward members only) ${ }^{2}$

\begin{tabular}{|c|c|c|c|c|}
\hline $\begin{array}{l}\text { Wards } \\
5\end{array}$ & $\begin{array}{l}\text { Sex } \\
\text { Male-2, } \\
\text { Female-2 }\end{array}$ & $\begin{array}{l}\text { Ethnicity/ Caste } \\
\text { Ind-2, dalit-1; BC-1 }\end{array}$ & $\begin{array}{l}\text { Education } \\
\text { Sec-2; LS-2 }\end{array}$ & $\begin{array}{l}\text { Occupational Status } \\
\text { Social worker-1; Enterprenur-1, } \\
\text { Farmer-? }\end{array}$ \\
\hline 6 & Male-2, & Ind-3, dalit-1; & Int-2; Sec-1; & Social worker-1; Enterprenur-2, \\
\hline 8 & $\begin{array}{l}\text { Female-2 } \\
\text { Male-2, } \\
\text { Female-2 }\end{array}$ & Ind-2, dalit-1; BC-1 & $\begin{array}{l}\text { LS-1 } \\
\text { Bach-2; Int-2 }\end{array}$ & $\begin{array}{l}\text { Farmer-1 } \\
\text { Social worker-1; Enterprenur-2, } \\
\text { Farmer-1 }\end{array}$ \\
\hline 9 & $\begin{array}{l}\text { Male-3, } \\
\text { Female-1 }\end{array}$ & Ind-2, dalit-1; BC-1 & Sec-1; LS-3 & Social worker-2; Farmer-2 \\
\hline 9 & $\begin{array}{l}\text { Male-1, } \\
\text { Female-3 }\end{array}$ & Ind-3, dalit-1 & Bach-1; LS-3 & Enterprenur-3; Farmer-1 \\
\hline Total (5) & $\begin{array}{l}20(M 10 \\
\& \text { F 10) }\end{array}$ & $\begin{array}{l}\text { (Ind-12; Dalit-5, } \\
\text { B-C-3) }\end{array}$ & $\begin{array}{l}\text { (LS-9, Sec-4, } \\
\text { Int-4, Bachelor-3) }\end{array}$ & $\begin{array}{l}\text { (Politician-0, Social worker-5, } \\
\text { Enterprenur-8, Farmer-7) }\end{array}$ \\
\hline
\end{tabular}

2 Indications: M (male), F (female), LS (lower secondary), Sec (secondary), Int (Intermediate), Bach (bachelor), BC (Brahman-Chhetri), Ind (indigenous nationalities), etc. 


\section{General Profile of Public Officials}

Findings regarding the sex of public officials of this municipality revealed that there was gender equality (Table 4). Out of 30 officials, 18 are male and following this 12 female. This kind of participation of female in administrative sector of local government presents that the female's issues and problems faced while getting administrative service delivery are easily addressed. Inclusively, the involvement of different caste and ethnicity in administrative service delivery has become an essential part for inclusive development. Hence, the researcher analysed to involvement of different castes and ethnicity of public officials in perspective of inclusion. According to above table, Brahmin and Chhetri were more in governmental job with 15 officials in this municipality. Following this, there was Janjati with 11 officials. Finally, very low volume in governmental job was occupied by Dalit with 3 people and by Madhesi with just a person only) in this municipality.

The selected wards in the municipality has all together 30 staffs ranging from administrative chief to office assistant. Among them, all the wards have executive officer as secretary of the ward, following with account officer, technician and office assistants. Most of the staffs are permanent, excluding contractually-paid social mobilizers and technical sub-engineers.

Generally those who are in public service, definitely they are educated but the higher level academic qualification matters in work efficiency. So, the researcher selected to assess the academic qualification of the public officials working in the municipality. Educational background directly boosts up effective service delivery in any organization. It means, without assessing academic qualification of the staffs, we cannot come in conclusion whether there are effective service delivery or not. Hence, the researcher found considering academic qualification of the staffs of the municipality that there were highly educated staffs. Out of total, 15 staffs were possessing intermediate level, while 10 did their Bachelor's degree. Following this, 3 staffs were having secondary level certification and remaining two of the officials just passed the SLC, i.e. secondary level.

Table 4. Human Resource and Bureaucratic Structure ${ }^{3}$

\begin{tabular}{llllll}
\hline Wards & Category & Sex & $\begin{array}{l}\text { Ethnicity/ } \\
\text { Caste }\end{array}$ & $\begin{array}{l}\text { Educational } \\
\text { Status }\end{array}$ & $\begin{array}{l}\text { Working } \\
\text { Years }\end{array}$ \\
\hline Ward no. 5 & Technician & M & BC & Bach & 1 \\
1 & Technician & M & Ind & Int & 1 \\
2 & Secretary & M & BC & Int & 10 \\
3 & Office assistant & F & Ind & Sec & 1 \\
4 & & & & & \\
Ward no. 6 & Secretary & F & Ind & Int & 20 \\
1 & Technician & F & BC & Bach & 2 \\
2 & Technician & M & Madhesi & Int & 5 \\
3 & Social mobilizer & F & Dalit & Int & 7 \\
4 & Social mobilizer & F & BC & Bach & 4
\end{tabular}

3 Indications: M (male), F (female), LS (lower secondary), Sec (secondary), Int (Intermediate), Bach (bachelor), $\mathrm{BC}$ (Brahman-Chhetri), Ind (indigenous nationalities), OA (office assistant), EO (executive officer), etc.

Nepalese Journal of Development and Rural Studies, Volume 15, 2018 


\begin{tabular}{|c|c|c|c|c|c|}
\hline Wards & Category & Sex & $\begin{array}{l}\text { Ethnicity/ } \\
\text { Caste }\end{array}$ & $\begin{array}{l}\text { Educational } \\
\text { Status }\end{array}$ & $\begin{array}{l}\text { Working } \\
\text { Years }\end{array}$ \\
\hline 6 & Office assistant & $\mathrm{F}$ & Ind & Low Sec & 1 \\
\hline \multicolumn{6}{|c|}{ Ward no.8 } \\
\hline 1 & $\mathrm{EO}$ & $\mathrm{M}$ & $\mathrm{BC}$ & Bach & 15 \\
\hline 2 & OA & M & $\mathrm{BC}$ & Bach & 2 \\
\hline 3 & Technician & M & $\mathrm{BC}$ & Int & 5 \\
\hline 4 & Technician & M & $\mathrm{B}-\mathrm{C}$ & Int & 19 \\
\hline 5 & $\mathrm{OA}$ & M & $\mathrm{BC}$ & Bach & 19 \\
\hline 6 & $\mathrm{OA}$ & $\mathrm{F}$ & $\mathrm{BC}$ & Int & 19 \\
\hline 7 & $\mathrm{OA}$ & $\mathrm{F}$ & Ind & Bach & 21 \\
\hline 8 & Acct Off & M & $\mathrm{BC}$ & Bach & 19 \\
\hline 9 & Technician & M & Ind & Int & 5 \\
\hline 10 & Technician & M & $\mathrm{BC}$ & $\mathrm{Sec}$ & 19 \\
\hline \multicolumn{6}{|c|}{ Ward no. 9} \\
\hline 1 & Secretary & M & $\mathrm{BC}$ & Int & 10 \\
\hline 2 & Technician & M & Ind & Bach & 3 \\
\hline 3 & Technician & M & Ind & Int & 1 \\
\hline 4 & Office assistant & $\mathrm{F}$ & Ind & Int & 4 \\
\hline 5 & Office assistant & $\mathrm{F}$ & Dalit & Low sec & 1 \\
\hline \multicolumn{6}{|c|}{ Ward no. 10} \\
\hline 1 & Secretary & M & Dalit & Int & 10 \\
\hline 2 & Technician & M & $\mathrm{BC}$ & Bach & 2 \\
\hline 3 & Technician & M & $\mathrm{BC}$ & Int & 5 \\
\hline 4 & Office assistant & $\mathrm{F}$ & Ind & Int & 3 \\
\hline 5 & Office assistant & $\mathrm{F}$ & Ind & Low sec & 1 \\
\hline Total (5) & 30 Staffs & $\begin{array}{l}(\mathrm{F}-12, \\
\mathrm{M}-18)\end{array}$ & $\begin{array}{l}\text { (Ind-11, BC- } \\
\text { 15, Dalit-3, } \\
\text { Madhesi-1) }\end{array}$ & $\begin{array}{l}\text { (Low Sec-3, Sec-2, } \\
\text { Int-15, Bach-10) }\end{array}$ & \\
\hline
\end{tabular}

(Institutional Survey, 2018)

The experience is also an important factor which directly plays vital role in making administrative service delivery effective. If there are well experience public officials, they easily perform the task with qualitative assurance. Hence, the researcher took the experience as one of the factor for effective service delivery. For this study, the experience component of the governmental official was determined to assess for profile of governmental officials of the municipality. The study reveals that the Gorkha municipality had newcomer staffs in the governmental job with few years of experiences. About 50 percent of governmental staffs in the municipality had 1-7 year working experience. Similarly, 40 percent staffs had 4-6 year working experience, while only the 10 percent staffs had good working experience ranging from 15-19 years.

Training is a process of learning. It includes to positive changes in knowledge, skills, and thinking of the staffs of organization. It is one of the most important components of the modern human resource development. It directly ensures capability for efficiency and effectiveness of the service 
delivery (Agrawal, 2015). Hence, the researcher has taken the training as one of the best variable for assessing effectiveness of the administrative service delivery. In the FGD among the officials, they were narrating about the lack of training and skill development activities for the new provision of local governance in the federal context. To reflect one of the statements:

The local people have expectations and aspirations much from the government, but there is a crucial lack of supportive policies and infrastructures to fulfil their needs and provide the services. Sometimes, we also face problem to convince the elected representatives about this issue. As government officials, we cannot go the verdict of the governmental rules and regulations, irrespective of the desire of people or the instructions of the leaders (Based on the personal conversation of the researcher with research participant on 4th June 2018).

\section{Opportunities of Service Delivery}

The Constitution of Nepal (2015) has been written and promulgated with essence of making local government more powerful and autonomous. It is for ensuring good governance strengthening local democracy for sustainable economic prosperity in order to change rural livelihood of people. Accordingly, the concept of local government was envisioned and internalized into 753 local levels in the nation. This restructuring of local levels opens to the door development opportunities in terms of economic dimension, political dimension, social dimension and environmental dimension. Especially, the opportunities of service delivery have been highlighted in terms of service delivery and administrative convenience.

The accessibility of service is one of the major opportunities of the local governments in the federal model. Principally, the local government is aimed to be established as close as possible with local people. Accordingly, the local governments of Nepal have been established very close to the local people. Large number of local bodies was transformed into local levels into only 753 . While doing this, it has raised question that how the accessibility to administrative service is ensured but powers and functions of subordinate office of the municipality i.e. ward office have been increased. Such devolution of powers and responsibility ensured the accessibility of administrative service to the local people. Regarding to the accessibility of the administrative service, the executive officer of the municipality responded that this kind of local government is for the local levels. The government of Nepal has devaluated powers and responsibility to the local government relating to vital registration. The LSGA 1999 and Regulation 2000 also provided administrative service relating to the vital registration. But the LGOA, 2017 has enlisted more functions relating to administrative service likes to provide verification and recommendation letter in English medium, recommend to open new primary school, to recommend for caring and rearing to orphan and needy people, to provide registration, operating permission, to renew and dismiss local cooperative organization, to provide registration, operating permission and to renew and dismiss to local radio station by 100 Watt, to provide and distribute land registration certificate etc.

The accessibility of these administrative service save both time and money of the local people. It is opportunity for the local people to get service at their door. It creates multiplier effect for transformation of rural life. The local people can get their service within their separate time saving both money and time. They can invest their time and money in productive sectors which assist directly to uplift their economic condition. Above data also justified that more service receiver have got 
their service within half day. The researcher further inquired to mayor of the municipality about the opportunity created after local election and restructuring local levels. He responded with smile that the local service receivers have got their guardian. They come to office of municipal/ ward and directly visit us to ask where to contract for the particular service. He told to me that they humbly responded them with required documents. Particularly, he said that this type of administrative service mechanism has ended to go Kathmandu to get operating permission of FM Radio, it has ended to Kathmandu to get registration business firm, it has ended to go Kathmandu to get operating permission of general hospital and Nursing Home, etc. Hence, the accessibility to administrative service is one of the opportunities of the local government in federal context.

The administrative convenience is also one of the important opportunities of the local government in federal context. The term administrative convenience is a broad which covers to digitalized service delivery, waiting room for service receivers, compensation based citizen charter board, etc. The local government in federal has administrative convenience. The administrative convenience also supports to local people to get administrative service. With the accessibility of Internet, the service receiver can get information about the tax levied to the municipality through websites of the municipality. Like other information can be easily accessed through the websites of the municipality. It means, the administrative convenience also saves time and money of the service receivers.

The researcher tried to gain information about the opportunities of the local government in federal context from the Executive Officer of the municipality, the Mayor of the municipality and the Chairperson of selected ward offices. Regarding to this, the researcher found that the computer system has been already installed in administrative service delivery mechanism to accelerate effectiveness of the service delivery. The computer system has been used in making receipt of revenue payment/fee payment at municipal office, to prepare recommendation letter and to provide other certificate. The date base has been developed to up- date old aged and differently able people. The web site has been developed. All the required information is in process for entry in web site. The municipality has not sufficient building to delivery administrative service from separate sections. However, the municipality has managed waiting room for the service receivers. It has been well managed with ceiling fan and television. The social mobilizers visited to different village under the jurisdiction of the ward office to collect information about the old aged citizens and differently able people.

For the administrative convenience, one of the chairperson of a ward office responded that when he was absent due his meeting at district level or municipality level, he requested to a member of ward committee to perform the task of the chairperson. He further said that:

We are servant of local people not representatives. The government has provided different functions for serving local people. So, when we go to meeting due our district level meeting and municipality level, the service receivers' administrative service cannot be completed. Therefore, I requested a member of ward to come to the ward office and perform task honestly (Based on the personal conversation of the researcher with research participant on 6th June 2018).

Therefore, the local government has many opportunities. The implementation and operationalization of the opportunities are determined by the locally elected representatives. When they do have willing power to make administrative more convenience and comfortable, they can it easily. Hence, constitutionally, the local government in federal context has opportunity of administrative convenience. 


\section{Responsible and Accountable Public Officials}

The local government in federal context has another opportunity in term of administrative service delivery is responsible public officials. Generally, it is argued that the public officials are responsible as much as possible when they are close to the local peoples. The researcher asked question to the service receiver how much the public officials are responsible and accountable towards the service receivers. He then observed to public official's presence to the ward office/municipal office. He found that all the public officials came to the office on time. He didn't see any public officials misusing their time. All were busy in their tasks providing administrative service. Further, the researcher inquired with Mayor of the municipality about the performance of the public officials in local government regarding in federal context after local election. He responded that the all the required human resources weren't available in the situation. It was very hard to accomplish administrative tasks by limited numbers of the human resource. However, all the staffs were honest, responsible and accountable to their tasks. Therefore, the administrative service delivery got smoothness.

\section{Challenges of Service Delivery}

The challenges of service delivery practices have been examined and appraised in terms of economic resources, human resources and types of administrative service delivery offering by the municipality. The economic challenge is major challenge of the local levels for effective service delivery in federal context. The Constitution of Nepal ha provisioned many functions to the local level. The implementation of the given functions and public services to the local people with efficient and effective way, it requires economic resources. Locally, the main economic resource is natural resource i.e. river related resources and forest related resources which are under the jurisdiction of federal, province and local levels. According to Constitution of Nepal the federal government will provide equalization grant, counterpart grant, special grant and conditional grant. The equalization grant is not for making administrative service delivery effective as provisioned in prevision grant allocation mechanism. It means, to maintain the economic capital, source of local revenue is major. However, in the municipality, the major economic resources local market, river related resources, forest related resources, micro level industries like rice mill, furniture, etc. There are not big industries. It means coverage of revenue is limited. It results low collection of revenue. It directly affects to the municipality in terms of providing effective service delivery.

Likewise, this study found that there was a challenge of not having required human resources for making effective administrative service delivery. While doing observation, the researcher found that a single ward secretary was performing the administrative functions of the service receivers of two wards. Such incident was found in two ward offices whereby joint ward office was there. It means the secretary had double work load. Such situation directly challenges to the effective administrative service delivery. According to Local Level Operation Ordinance, in a ward office, there are at least three public officials namely, ward secretary, administration and Assistance Accountant and office assistance. Regarding to this provision, the researcher didn't found there rather, there were ward secretary, social mobilizer and office assistance. The social mobilizers were under the LGCDP budget scheme. Similarly due to problem of human resource the recommendation letter in English medium was not effective at ward office.

The researcher further inquired with mayor and executive office of the municipality regarding to this human resources availability. The mayor responded that required public officials were performing 
their tasks. He further told that the municipality had been overcoming the challenges of the human resources. The executive officer of the municipality responded that to fulfil the required vacancy in the municipality to provide public service, the municipality hired the public officials locally through free competition.

In the case of types of administrative service delivery, According to the elected representatives and government officials the Gorkha municipality has offered different kinds of services to the people (Table 5). During the observation it was found that almost all the above-mentioned services used to take a minimum of five minute to a maximum of 20 minutes for the service accomplishment. In normal cases, all the services would be provided within the same day. The municipal council of Gorkha municipality has further issued an ordinance to make uniformity in the service charges and tax systems for the various kinds of services. For example, there was a provision of taking NRs 100 for the offering of citizenship card in all the wards, while electricity meter installation service charge was categorized according to the distance and length of the transmission. The researcher, however, has consulted to the local people and they said that all the service charges in the municipality were quite expensive so as to the poor classes people could not afford as such. All the ward offices were granted with rights to collect taxes and service charges as per the municipal council.

Gorkha municipality has recently completed its third Municipal Assembly announcing approximately NRs. 80 crore budgets for FY 2075/076. Being held in 31st of Asar, the program was the continuation of the program held in 10th of Asar, 2075 B.S. The budget announced for 075/076 fiscal year for programme and regulation was NRs. 79 crore 93 lakh 72 thousand 4 hundred and 47 rupees. The sources of the budget are as follows: from revenue 4 crore 12 lakhs, 24 crore 14 lakh 85 thousand from NG (bittiyesamanikaran), 9 crore 10 lakh 45 thousand from distribution of revenue, 27 crore 52 lakhs from NG (sasartanudaan), 8 crore 10 lakh from social security allowance leaving it to a total of 68 crore 87 lakh 31 thousand and 1 crore 35 lakhs 73 thousand from provincial government, 74 lakh 68 thousand 4 hundred and 47 from revenue distribution leaving it to a figure of 2 crore 10 lakhs 41 thousand 447 rupees and 60 lakhs from road board Nepal, 3 crore from municipality development fund leaving it to total figure of 78 crore 69 lakhs 72 thousand 4 hundred and 4 rupees. Insufficient fund of Nrs. 1 crore 24 lakhs would be fulfilled by loan procedures from central government.

Table 5. Types of Administrative Service Delivery

\begin{tabular}{llcl}
\hline S. N. & Categories & Time Taken- Minutes) & Service Charge-NRs \\
1 & Issue letter to the citizenship & 10 & 100 \\
2 & Issue of general Nepali letters & 10 & 200 \\
3 & General English issue letters & 10 & 500 \\
4 & Land registration ownership & 15 & $350-500$ \\
5 & Electricity meter installation letter & 15 & $200-10000$ \\
6 & Vital event registrations & 10 & 300 \\
7 & Inherent property division letter & 15 & $500-800$ \\
8 & Passing of designing of Home map & 20 & 500 \\
\hline
\end{tabular}




\section{Conclusion}

The municipality is not institutionally strong in terms of physical resources. The two ward officer were operating and providing public services from the joint ward office. The building of ward office and municipal officer was not sufficient and not friendly for people with disabilities. The public officials were capable and efficient for the service delivery. There were young and newly entered human resources as public officials. So, they were active and excited to serve people within federal model. The elected representatives are neither highly strong neither weak to formulate plans policies for making effective service delivery. The chairpersons of three ward offices were academically capable and they had good knowledge for administration as well since they were involved in social work and own business-entrepreneurship.

With the restructuring to local bodies into local levels and local election, the administrative service delivery has been effective in comparison to previous practice. The more service receivers got services within the allocated time. The three offices - two ward office and municipal offices have already started computerized service delivery. Hence, there is progressive changes and transformation of administrative service delivery. The newly restructured municipality in federal polity has opened the door of many opportunities. The municipality has offered the opportunities in term of administrative accessibility, administrative convenience and accountable and responsible bureaucracy. However, the municipality has facing so many challenges while operationalizing the powers, authorities and jurisdiction regarding to administrative services. Firstly, the municipality has been facing challenges of physical infrastructure. Likewise, not having sufficient economic resource is another challenge. Another challenge is challenge of human resource making the administrative service delivery ineffective with unavailability of required human resources to operationalize given administrative jurisdictions to the local levels.

\section{References}

Adhikari, R. (2010). Local governance institution in Nepal: Status and challenges. Retrieved from http://www.academia.edu/1831963/Local_Government_Institutions_in_Nepal_Status_and_ Challenges

Agrawal, G. R. (2015). Dynamics of human resource development in Nepal (6th ed.). Kathmandu: M. K. Publishers and Distributer.

Atkinson, D. (2002). Local government, local governance and sustainable development: Getting the parameters rights. Cape Town, South Africa: Human Social Science Council.

Baral, B. (2004). Yesto hunuparcha Rajyako samrachna. Kathmandu: Bijayapur Prakashan Samitee.

Bhatta, B. D. (1987). Development administration in Nepal. Kathmandu: Mrs. Indira Bhatta.

Bhatta, B. D. (1990). Decentralization in Nepal. New Delhi: Reliance Publishing House.

Central Bureau of Statistics (CBS). (2014). National population and housing census 2011 (Volume 06). Kathmandu: Government of Nepal.

Elazar, D. J. (1987). Exploring federalism. Tuscaloosa, AL: University of Alabama Press.

Election Commission of Nepal. (2017). Local election bulletin. Kathmandu: Election Commission of Nepal.

Flick, U. (2014). An introduction to qualitative research. London: Sage Publications. 
Gamper, A. (n.d.). A global theory of federalism: A nature and challenges of federal state. German Law Journal, 6(10), 1297-1318. Retrieved from https://static1.squarespace.com/ static/56330ad3e4b0733dcc0c8495/t/57634f3e893fc07fb7eebfcd/1466126143493/GLJ_ Vol_6_No_10_Gamper.pdf

Joshi, B. L., \& Rose, L. E. (1966). Democratic innovation in Nepal: A case study of political acculturation. Berkeley: University of California Press.

Khanal, R. (2006). Local governance in Nepal: Democracy at grassroot. Kathmandu: Smirti Books.

Miles, M. B., Huberman, A. M., \& Saldana, J. (2013). Qualitative data analysis. London: Sage Publications.

Lawoti, M. (2005). Towards a democratic Nepal: Inclusive political institutions for a multicultural society. New Delhi: Sage Publications.

LBMB. (2015). Constitution of Nepal. Kathmandu: Law Book Management Board.

LBMB. (2017). Local governance operation act, 2017. Kathmandu: Law Book Management Board.

NFVDCN (2014). Federalism and local self-governance. Kathmandu: National Federation of Village Development Committee Nepal.

Pant, S. D. (1989). Aspects of decentralization under panchayat democracy. Kathmandu: Research Center for South Asia

Pieterse, J. N. (2010). Development theory. New Delhi: Sage Publications India Pvt. Ltd.

Pokharel, B. (2004). Rural political economy of Nepal. Kathmandu: New Hira Books Enterprises.

Sanyal, D. (2017). Transitional challenges of local body restructuring. Retrieved from <http:// nepalekhabar.com/2017/03/74440

Sapkota, M., \& Tharu, M. (2016). Development a contested discourse: An overview. Nepalese Journal of Development and Rural Studies, 13(1), 13-28. 